УДК 811.161.2’373.421-022.338

DOI https://doi.org/10.26661/2414-1135-2021-83-41

\title{
КРИТЕРІЇ ВИЗНАЧЕННЯ МОРФОЛОГІЧНОЇ ВАРІАНТНОСТИ В УКРАЇНСЬКОМУ МОВОЗНАВСТВІ
}

\author{
Шмілик І. Д. \\ кандидат філологічних наук, \\ старший викладач катедри украӥнської мови \\ Начіональний університет «Львівська політехніка» \\ вул. Степана Бандери, 12, Львів, Україна \\ orcid.org/0000-0002-3289-7997 \\ shmilykira@ukr.net
}

Ключові слова: варіант, варіант слова, морфологічні варіанти, форма слова, словозмінна варіантність.
У статті подано різні погляди щодо тлумачення терміна «варіант» і трактування термін сполуки «варіант слова». Описано різні класифікації варіантів слів (акцентуаційні, фонетичні, орфоепічні, орфографічні, словотвірні, граматичні, останні 3 яких мовознавці ототожнюють із морфологічними або поділяють на морфологічні й синтаксичні). Серед різноманітної класифікації варіантів слів грунтовно проаналізовано морфологічні варіанти й виокремлено такі особливості: форми того самого слова; тотожність лексичного й граматичного значення; наявність спільної або варіантної словозмінної основи (братові/брату - спільна, золотому/золотім - варіантна); наявність варіантних флексій (нова - новая); наявність формотворчих суфіксів (ім'ям - іменем); неоднакове поширення в стилях літературної мови; взаємозамінність у тій самій позиції. Вказано на інші чинники, якими може бути зумовлена морфологічна варіантність, зокрема: зміною і словозмінної основи, i флексій (сльозами - слізьми), акцентуаційними змінами (стола-столу), фонетичними й акцентуаційними змінами (на тоці - на току), зміною лексичного значення слова (духу - духа, каменю - каменя), варіюванням граматичної категорії роду при змінній або незмінній формі слова (зал ч.р. - зала ж.р. - не потребує контексту, купіль - ч.р. і ж.р. потребує контексту), варіюванням форм того самого роду (вовкулак ч.р. - вовкулака ч.р., постіль ж.р. - постеля ж.р.). Зазначено, що мовознавці другої половини XX ст. використовували різні терміни на позначення спільнокореневих утворень із тотожним змістом і деякими видозмінами форми, а саме: паралельні форми, варіантні закінчення, паралельні закінчення, паралельні граматичні форми, морфологічні варіанти, варіантні утворення, варіантні форми тощо. Також вказано на дискусійне питання в українській лінгвістиці про розмежування понять «паралельна форма», «дублет» і «варіант» і на доречність використання терміна «варіант», який найбільш повно виражає суть явища варіювання мовних засобів. Зазначено доцільність вживання терміносполуки «варіанти форм слова», якщо йдеться про морфологічну варіантність, а також поняття «морфологічна варіантність», «словозмінна варіантність», «варіанти форм слова» потрактовано як синоніми. 


\title{
CRITERIA FOR DETERMINATION OF MORPHOLOGICAL VARIABILITY IN UKRAINIAN LINGUISTICS
}

\author{
Shmilyk I. D. \\ Candidate of Philological Sciences, \\ Senior Lecturer at the Department of Ukrainian Language \\ Lviv Polytechnic National University \\ Stepan Bandera str., 12, Lviv, Ukraine \\ orcid.org/0000-0002-3289-7997 \\ shmilykira@ukr.net
}

Key words: variant, word variant, morphological variants, word form, word-changing variance.
The article presents different views on the interpretation of the term "variant" and the interpretation of the term "variant of the word". Different classifications of word variants are described (accentual, phonetic, orthoepic, orthographic, word-forming, grammatical, the latter of which linguists identify with morphological ones or divide them into morphological and syntactic). Among the various classifications of word variants, morphological variants are thoroughly analyzed and the following features are singled out: forms of the same word; identity of lexical and grammatical meaning; the presence of a common or variant word basis (братові/брату - common form, золотім/ золотому - variant form); the presence of variant inflections (нова/новая); the presence of word-forming suffixes (ім'ям-іменем); unequal distribution in the styles of literary language; interchangeability in the same position. Other factors that may cause morphological variability are indicated, in particular: the change of word-change basis and inflections (сльозами-слізьми), accentuation changes (стола-столу), phonetic and accentuation changes (на тоці-на току), change of the lexical meaning of the words (духу-духа, каменю-каменя), variation of the grammatical category of the gender with variable or invariant form of the word (зал masc.gender - зала femin. gender does not require context, купіль - masc. and femin. - does need context), variation of forms of the same gender (вовкулак masc. gender - вовкулака masc. gender, постіль femin. gender - постеля femin. gender). It is noted that linguists of the second half of the twentieth century used different terms to denote common-root formations with identical meaning and some variations of form, namely: parallel forms, variant endings, parallel endings, parallel grammatical forms, morphological variants, variant formations, variant forms, etc. It also points to the controversial issue in Ukrainian linguistics about the distinction between the concepts of "parallel form", "doublet" and "variant" and the appropriateness of using the term "variant", which most fully expresses the essence of the phenomenon of language variation. The practicality of using the term "variants of word forms" in the case of morphological variance is stated. Additionally, the concepts of "morphological variance", "word variance", "variants of word forms" are interpreted as synonyms.
Постановка проблеми. Розвиток літературної мови - багатовекторний процес, одним із напрямів якого є тенденція до уніфікування та нормалізації граматичної системи. Усталення мовної норми пов'язане $з$ явищем варіантности, яке привертало увагу багатьох дослідників: О. Васецька, I. Вихованець, с. Єрмоленко, А. Загнітко, Т. Коць, I. Кузьма, О. Тараненко, І. Царалунга, В. Юносова та інші. Актуальність теми полягає в потребі розвитку теорії морфологічної варіантности, адже досі в українському мовознавстві немає одностайної думки щодо визначення поняття «морфологічний варіант».

Мета цього наукового дослідження - проаналізувати теоретичні аспекти морфологічної варіантности в українському мовознавстві. Завдання - узагальнити комплекс теоретичних питань, пов'язаних із вивченням поняття варіантности, і в цьому контексті виокремити ознаки морфологічних варіантів. 
Об'єкт дослідження - варіантність в українському мовознавстві.

Предмет дослідження - морфологічні варіанти.

Виклад основного матеріалу. На певних етапах розвитку мови явище варіантности є виявом динамічного характеру норми літературної мови. Варіант є результатом модифікування різних аспектів вираження мовної одиниці - фонемного, морфемного або лексичного складу, місця наголосу, парадигми відмінювання, порядку слів тощо.

У сучасній українській лінгвістиці термін варіант має кілька тлумачень:

- «формальна видозміна або різновид (реалізація) тієї самої мовної одиниці на різних рівнях мови - фонетичному, морфемному, лексичному, синтаксичному;

- стилістичне поняття, за яким допускаються паралельні форми (комбінаторні, факультативні та стилістичні);

- різновид, один зі способів вираження, конкретна мовленнєва реалізація якої-небудь мовної одиниці;

- морф, що перебуває у відношенні вільної дистрибуції зі співвідносним (співвідносними) морфом (морфами)» [1, Т. 1, с. 99-100].

Серед мовознавців другої половини $\mathrm{XX}$ початку XXI ст. немає одностайности щодо трактування терміносполуки варіант слова. Зокрема, на думку М. Карп'юка, це «різновиди однокореневих словоформ, які не зачіпають їх внутрішньої сторони (план змісту) i, охоплюючи всі рівні мови, виявляються на певному етапі мовного розвитку» $[2$, с. 74$]$. Подібне тлумачення подано i в «Короткому тлумачному словнику лінгвістичних термінів» за ред. С. Срмоленко (2001) [3, с. 26-27]. «Словник лінгвістичних термінів» Д. Ганича, I. Олійника репрезентує інше визначення: «видозміна або різновид мовної одиниці, фонеми, морфеми, слова» [4, с. 31]. Дослідники також розглядають варіант слова в широкому та вузькому значеннях: 1) видозміни, паралельні форми існування мовної одиниці, що модифікують різні аспекти ії вираження (фонемний, морфемний або лексичний склад, місце наголосу, парадигму відмінювання, порядок слів і т.ін.), але не порушують принципу іiі тотожності; конкретні форми вираження, реалізації в мовленні умовно-абстрактних одиниць - фонеми, морфеми, лексеми [5, с. 62-63]; 2) засоби, один з яких несе додаткову інформацію чи смисловий відтінок, стилістичне навантаження; близькі за функціями засоби тієї самої мови, рівноцінні, не диференційовані [6, с. 38-39] тощо.

Отже, поняття варіанти слова мовознавці тлумачать як видозміни того самого слова, які постають регулярно відтворюваними і яким властива морфологічно-словотвірна тотожність, спільність лексичного та граматичного значення з послідовним розрізненням у фонетичному (вимова звуків, склад фонем, місце і статус наголосу, поєднання усіх цих ознак), формотворчому (суфікси, флексії, префікси тощо) аспектах $[4$, с. $31 ; 1$, с. 102]. Варіанти слів - це історичне явище, тому можна простежити, як один із варіантів стає застарілим i переходить у пасивний запас мови. Проте в мові $\epsilon$ й такі слова, які стають застарілими в одному стилі літературної мови, але продовжують існувати в іншому. Відповідно, багато слів, які вийшли 3 ужитку, зберігаються в поетичному мовленні i не сприймаються як застарілі.

У мовознавстві, зокрема в українській лінгвістиці, подано різні класифікації варіантів слів. До прикладу, на синхронному рівні в «Словнику лінгвістичних термінів» Д. Ганича, I. Олійника подано лише фонетичні (онук-внук), акиентуачійні (опові́дач-оповіда́ч), морфологічні (бурлак-бурлака) та семантичні варіанти слів [4, с. 31]. Однак «Короткий тлумачний словник лінгвістичних термінів» за ред. С. Єрмоленко репрезентує такі варіанти слів: фонетичні (вирій-ирій), акцентуаційні (ді́вчина-дівчи́на), орфоепічні (соня(чн)ий і соня(шн)ий), словотвірні (вечірній-вечоровий), морфологічні (зал-зала) та семантичні (світла кімната, світла тканина, світла душа) [3, с. 27].

А. Загнітко запропонував класифікацію варіантів, яка враховує еквівалентність граматичного значення, граматичну системність і регулярність взаємозамінности, однорідність порівнюваних структур та стильову належність. Мовознавець виокремив категоріально-граматичні, лексикограматичні, семантико-граматичні, фонетикограматичні, словотвірно-граматичні, граматикостилістичні та граматико-стильові варіанти [7, с. 126-127]. Натомість О. Тараненко розрізняе варіанти слів залежно від структури та формальних модифікацій: 1) акцентуаційні, тобто за місцем наголосу (ма́буть-мабу́mь); 2) фонетичні, тобто 3 різним звуковим складом (не пов'язані з чергуванням звуків, крім орфоепічних, і парадигматичними змінами слова). Сюди належать чергування в-у, i-й, 3-із-зі; різні форми транслітерації чи транскрипції іншомовних слів (гикати-ікати, бітос-бігос; Ван Кліберн-Вен Клайберн); 3) орфоепічні, які виділяються в межах двох попередніх типів залежно від норм вимови без відображення на письмі (ГетеГете); 4) орфографічні, тобто без відображення у вимові (Парнас -парнас); 5) словотвірні, які розрізняються видозмінами морфем і взагалі частин слова при словотворенні, порядком компонентів (тишком-нишком і нишком-тишком); 6) комбіновані варіанти слів, що одночасно розрізняються більш як однією з названих ознак (жстттє'вий жстттьови́й); 7) морфологічні [5, с. 62-63]. 
П. Дудик виокремив такі види варіантности: семантико-лексичні (здебільшого виявляється у відносних (відтінкових) синонімах); лексико-граматичні (певне слово тільки своєю морфологічною формою вносить зміну до семантики того самого сполучення слів) та граматичні (морфологічні) (паралельні форми відрізняються не семантично, а лише граматично (морфологічно), фонетично й стилістично) [8, с. 296-297].

На думку Т. Коць, варіантність в історії літературної мови, а саме в іії писемному різновиді, «в плані діахронії і в плані синхронії виявляється на рівні лексичних, морфологічних і синтаксичних одиниць» $[9$, с. 85]. Розрізняючи три групи варіантів (лексичні, морфологічні та синтаксичні), останні дві мовознавець об'єднує під загальним терміном граматичні варіанти слів - «функціонально тотожні граматичні одиниці, які мають регулярні відмінності граматичної форми» [9, с. 87].

Із-поміж різноманітної класифікації варіантів грунтовного аналізу потребують саме морфологічні варіанти. Мовознавці другої половини $\mathrm{XX}$ ст. використовували різні терміносполуки на позначення спільнокореневих утворень із тотожним змістом і деякими видозмінами форми, а саме: паралельні форми [10, с. 35]; паралельно існуючі варіанти [11, с. 18]; варіантні закінчення, паралельні закінчення, паралельні граматичні форми [12, с. 48]; морфологічні варіанти, варіантні утворення [10, с. 35]; варіантні форми, паралельні засоби [13, с. 14] тощо. В. Поставний зазначав, що це «форми слова, які виникають внаслідок паралельного вживання флексій слів (гурта-гурту, крилами-крильми) і тих афіксів, які виконують формотворчу, а не словотворчу роль (ім'ям-іменем, плем'ям-племенем). Такі варіантні форми можуть мати різну функціональну активність у сучасному слововживанні, неоднакове поширення в стилях літературної мови, відрізнятися своїм походженням, часом і місцем виникнення тощо» $[10$, с. 35$]$.

У тогочасній українській лінгвістиці дискусійним було питання розмежування понять «паралельна форма», «дублет» і «варіант». М. Карп’юк вважав, що терміносполука «паралельна форма» i термін «дублет» $є$ невдалими на позначення спільнокореневих утворень із певними видозмінами форм при збереженні єдиного змісту. Натомість учений вважав доречним використання терміна варіант, що «найбільш повно 3 інших існуючих виражає суть явища варіювання мовних засобів» [2, с. 74]. Учений зазначив, що поняття «паралельна форма» і «дублет» - це перші своєрідні ластівки, які сигналізували про існування в межах синонімів відмінних одиниць мовлення, i вони мають бути підпорядковані як вужчі більш широкому за змістом терміну «варіант» [2, с. 75].
На початку XXI ст. у мовознавстві морфологічну варіантність потлумачено як «видозміни слів чи форм слова, які при семантичній тотожності всіх членів варіантної пари чи ряду мають відмінності в граматичному оформленні» $[14$, с. 3]. Згодом О. Тараненко вказував, що ці варіанти характеризуються: 1) наявністю різних формотворчих афіксів та парадигмою відмінювання (дієвідмінювання): сліпуче - сліпучо (присл.), затискати - затискувати, итаньли - штанам - штанями; наявністю повних і коротких форм: жодний - жоден; 2) варіантністю граматичних категорій при змінній або незмінній формі слова, особливо на рівні роду або числа: тонт (ч.р.) і гонта (ж.р), лелека (ч.p. і ж.р., рукави - рукава); 3 варіантним оформленням того самого роду: вовкулак - вовкулака (ч.р.), постіль - постеля (ж.р.) $[5$, c. 63$]$.

Т. Коць до морфологічних варіантів зараховує «формальні словозмінні модифікації, що за будьяких умов не змінюють лексичного і граматичного значень і стилістичної однорідності» [9, с. 87]. На думку дослідниці, це афіксальні різновиди словоформ ыз граматичним значенням відмінка, роду, числа, часу і способу. На рівні морфології формальна варіантність можлива в тих випадках, коли, «зберігаючи одне значення, дві різні форми можуть бути взаємозамінними в одній і тій самій позиції» [9, с. 87].

Принцип тотожности - це основний критерій ідентифікації варіантів, який полягає в тому, що мовні одиниці, які розглядаються як варіанти, $€$ насправді не різними фонетичними, морфологічними, лексичними одиницями тощо, а виявом однієї мовної одиниці, тобто тотожним $є$ не значення, а саме одиниці. Варіанти слова - «це лише різні форми існування одного й того ж слова» [15, с. 33]. Формотворчі афікси, не функціонуючи для утворення нових слів, цілком можуть бути компонентом модифікації плану вираження слова, якщо вони не порушують морфемної структури, лексичного та граматичного значення слова. Такі мовні одиниці називаємо морфологічними варіантами.

Морфологічні та словотвірні варіанти - поняття не тотожні. До словотвірних варіантів належать такі слова, які при спільності кореня і лексичного значення мають різну словотвірну будову $[16$, с. 21$]$. Як зазначила I. Кузьма, словотвірні варіанти - це «похідні, що мають близьку або тотожну словотвірну і лексичну семантику; утворені від тої самої мотивуючої бази за допомогою суфіксів-аломорфів або вільних простих чи складних похідних варіантів одного форманта (лицьовий-лицевий), а також похідні, утворені шляхом додавання того самого суфікса до варіантних твірних основ (важенький-важкенький)» 
[17, с. 178-179]. Словотвірна варіантність слова як лінгвостилістична категорія особливо цінна тим, що збільшує виражальні можливості української синоніміки [18, с. $40 ; 17$, с. 179].

Якщо йдеться про морфологічну варіантність, то, вважаємо, доцільно вживати саме терміносполуку «варіанти форм слова», адже форма слова-це «граматичні видозміни слова, його морфологічні різновиди, які стосуються явищ словозміни і яким притаманний певний комплекс граматичних значень та їхніх формальних показників» $[19$, с. 61]. Терміносполуку «форма слова» використовують як щодо певного конкретного слова, так і щодо класу однофункційних граматичних форм різних слів. Відповідно, формальними показниками $\epsilon$ морфеми (закінчення, формотворчі суфікси). Для варіантів форм слова характерні фонемна близькість, наділеність тотожним граматичним значенням і здатність замінити один одного в складі тієї ж словоформи, напр.: дієсл. закінчення 1 ос. мн. наказового способу -імо/ -iм (ходімо, ходім); суфікси інфінітива -ти/-ть (жити, жить); закінчення прикметників М.в. одн. ч. і с.р. -ім/-ому (у синім/у синьому) тощо. Оскільки морфологічна форма слова $є$ поєднанням основи та закінчення, то, відповідно, будь-який елемент морфологічної форми, який варіює, розглядаємо як морфологічну варіантність, а також поняття морфологічна варіантність, словозмінна варіантність, варіанти форм слова вважаємо синонімами.

Висновки і перспективи подальших розробок. Отже, спираючись на різні думки мовознавців щодо морфологічної варіантности, розглядатимемо цю терміносполуку в широкому розумінні, виокремивши такі іiі особливості: форми того самого слова; тотожність лексичного й граматичного значення; наявність спільної або варіантної словозмінної основи (братові/брату - спільна, золотому/ золотім - варіантна); наявність варіантних флексій (нов $a$ - новая); наявність формотворчих суфіксів (ім'ям-іменем); неоднакове поширення в стилях літературної мови; взаємозамінність у тій самій позиції. Морфологічна варіантність також може бути зумовлена такими чинниками: зміною і словозмінної основи, і флексій (сльозами - слізьми); акцентуаційними змінами (столㅁ-cmoлy); фонетичними й акцентуаційними змінами (на тоці-на току); зміною лексичного значення слова (духу духа, каменю - каменя); варіюванням граматичної категорії роду при змінній або незмінній формі слова (зал ч.р. - зала ж.р. - не потребує контексту, куnіль - ч.p. і ж.р. - потребує контексту); варіюванням форм того самого роду (вовкулак ч.р. - вовкулака ч.р., постіль ж.р. - постеля ж.р.).

Проблему, яку порушено в статті, не вичерпано цим науковим доробком. Вона потребує глибшого дослідження й опрацювання. Але завдяки таким науковим спостереженням удосконалено теоретичні засади дослідження явища варіантности в мовознавстві й критерії, за якими визначено, що таке морфологічні варіанти. Отримані результати дослідження можна використати для написання наукових праць із граматики.

\section{ЛІТЕРАТУРА}

1. Загнітко А. Словник сучасної лінгвістики: поняття і терміни: у 4 т. Донецьк : ДонНУ, 2012. Т. 1: А-Й. 402 с.; Т. 2: К-О. 350 с.

2. Карп'юк М.Д. «Паралельна форма», «дублет» чи «варіант»? Культура слова. 1978. Вип. 15. C. 70-75.

3. Українська мова. Короткий тлумачний словник лінгвістичних термінів / С.Я. Срмоленко, С.П. Бибик, О.Г. Тодор; за ред. С.Я. Срмоленко. Київ : Либідь, 2001. 222 с.

4. Словник лінгвістичних термінів / уклад.: Д.І. Ганич, І.С. Олійник. Київ : Вища школа, 1985. $360 \mathrm{c}$.

5. Тараненко О.О Варіанти мовних одиниць. Українська мова. Енциклопедія / редкол.: В.М. Русанівський, О.О. Тараненко, М.П. Зяблюк та ін. Київ : вид-во «Укр. енцикл.» ім. М.П. Бажана, 2004. С. 62-63.

6. Струганець Л. Диференційні ознаки норми літературної мови. Культура слова. 2011. № 74. C. 34-43.

7. Загнітко А. Проблеми правописної варіантності: система й узус (на матеріалі граматичних системних та узусних варіантів) Лінгвістичні студіi. 1998. Вип. 4. С. 126-132.

8. Дудик П.С. Стилістика української мови : навч. посібник. Київ : Вид. центр «Академія», 2005. $368 \mathrm{c}$.

9. Коць Т. Явище варіантності в історії літературної мови. Украӥнська мова. 2016. № 2. С. 82-91.

10. Поставний В.В. Морфологічні варіанти іменників. Украӥнська мова і література в школі. 1974. № 3. С. 35-44.

11. Мельничайко В.Я. До питання про граматичну синоніміку. Украӥнська мова і література в школі. 1970. № 9.

12. Сологуб Н.М. У цвіті - у цвіту. Рідне слово. 1974. Вип. 8. С. 45-51.

13. Вихованець І. У світі граматики. Київ : Рад. школа, 1987. $188 \mathrm{c.}$

14. Юносова В. Варіантність відмінкових закінчень іменників у сучасній українській літературній мові. Київ : Знання України, 2003. $126 \mathrm{c}$.

15. Зарінова М.В. Лексична варіантність в українській літературній мові кінця XIX - початку XX ст. : дис. ... канд. філол. наук : 10.02.01 / 
Інститут української мови НАН України. Київ, 2020.211 с.

16. Семиряк В.Д. Шляхи виникнення іменникових словотворчих варіантів. Мовознавство. 1971. № 5. C. 21-27.

17. Кузьма I. Словотвірна синонімія і словотвірна варіантність прикметників в українській мові. Львів : Літопис, 2006. 306 с.

18. Чабаненко В.А. Стилістичні можливості словотвірних варіантів. Украӥнська мова і література в школі. 1983. № 11. С. 38-40.

19. Вихованець I. Основні питання морфології. Граматика сучасної украӥнської літературної мови. Морфологія / І.Р. Вихованець, К.Г. Городенська, А.П. Загнітко, С.О. Соколова, за ред. К.Г. Городенської. Київ : Видавничий дім Д. Бураго, 2017. С. 19-68.

\section{REFERENCES}

1. Zahnitko A. (2012) Slovnyk suchasnoi linhvistyky: poniattia i terminy [Dictionary of modern linguistics: concepts and terms]: $\mathrm{u} 4 \mathrm{t}$. Donetsk : DonNU [in Ukrainian].

2. Karpiuk M. D. (1978) "Paralelna forma", "dublet" chy "variant"? ["Parallel form", “doublet" or "variant”?] Kultura slova. 15, 70-75 [in Ukrainian].

3. Ukrainska mova. Korotkyi tlumachnyi slovnyk linhvistychnykh terminiv (2001) [Ukrainian language. A short glossary of linguistic terms] / S.Ia. Yermolenko, S.P. Bybyk, O.H. Todor; za red. S.Ia. Yermolenko. Kyiv : Lybid [in Ukrainian].

4. Slovnyk linhvistychnykh terminiv (1985) [Dictionary of linguistic terms] / uklad.: D.I. Hanych, I.S. Oliinyk. Kyiv : Vyshcha shkola [in Ukrainian].

5. Taranenko O.O. (2004) Varianty movnykh odynyts. Ukrainska mova. Entsyklopediia [Variants of language units. Ukrainian language. Encyclopedia] / redkol.: V.M. Rusanivskyi, O.O. Taranenko, M.P. Ziabliuk ta in. K. : vyd-vo «Ukr. entsykl.» im. M.P. Bazhana, pp. 62-63 [in Ukrainian].

6. Struhanets L. (2011) Dyferentsiini oznaky normy literaturnoi movy [Differential features of the norm of literary language]. Kultura slova. 74, 34-43 [in Ukrainian].

7. Zahnitko A. (1998) Problemy pravopysnoi variantnosti: systema y uzus (na materiali hramatychnykh systemnykh ta uzusnykh variantiv) [Problems of spelling variance: system and usage (based on grammatical system and usage variants)]. Linhvistychni studii, 4, 126-132 [in Ukrainian].
8. Dudyk P.S. (2005) Stylistyka ukrainskoi movy [Stylistics of the Ukrainian language]: navch. posibnyk. K. : Vyd. tsentr «Akademiia» [in Ukrainian].

9. Kots T. (2016) Yavyshche variantnosti v istorii literaturnoi movy [The phenomenon of variability in the history of literary language]. Ukrainska mova. 2, 82-91 [in Ukrainian].

10. Postavnyi V.V. (1974) Morfolohichni varianty imennykiv [Morphological variants of nouns]. Ukrainska mova i literatura $v$ shkoli. 3, 35-44 [in Ukrainian].

11. Melnychaiko V.Ia. (1970) Do pytannia pro hramatychnu synonimiku [On the question of grammatical synonymy]. Ukrainska mova $i$ literatura $v$ shkoli. № 9 [in Ukrainian].

12. Solohub N.M. (1974) U tsviti - u tsvitu [In bloom - in bloom]. Ridne slovo. 8, 45-51 [in Ukrainian].

13. Vykhovanets I. (1987) U sviti hramatyky [In the world of grammar]. K. : Rad. Shkola [in Ukrainian].

14. Iunosova V. (2003) Variantnist vidminkovykh zakinchen imennykiv u suchasnii ukrainskii literaturnii movi [Variability of case endings of nouns in modern Ukrainian literary language]. K. : Znannia Ukrainy [in Ukrainian].

15. Zarinova M.V. (2020) Leksychna variantnist v ukrainskii literaturnii movi kintsia XIX-pochatku $X X$ st. [Lexical variability in the Ukrainian literary language of the end of the XIX beginning of the XX century]: dys. ... kand. filol. nauk: 10.02.01 / Instytut ukrainskoi movy NAN Ukrainy. Kyiv [in Ukrainian].

16. Semyriak V.D. (1971) Shliakhy vynyknennia imennykovykh slovotvorchykh variantiv [Ways of origin of noun word-formation variants]. Movoznavstvo. 5, 21-27 [in Ukrainian].

17. Kuzma I. (2006) Slovotvirna synonimiia $i$ slovotvirna variantnist prykmetnykiv v ukrainskii movi [Word-forming synonymy and wordforming variability of adjectives in the Ukrainian language]. Lviv: Litopys [in Ukrainian].

18. Chabanenko V.A. (1983) Stylistychni mozhlyvosti slovotvirnykh variantiv [Stylistic possibilities of word-forming variants]. Ukrainska mova $i$ literatura $v$ shkoli. 11, 38-40 [in Ukrainian].

19. Vykhovanets I. (2017) Osnovni pytannia morfolohii [The main issues of morphology]. Hramatyka suchasnoi ukrainskoi literaturnoi movy. Morfolohiia / I.R. Vykhovanets, K.H. Horodenska, A.P. Zahnitko, S.O. Sokolova; za red. K.H. Horodenskoi. K.: Vydavnychyi dim D. Buraho, pp. 19-68 [in Ukrainian]. 